\title{
Hanford タンクのクリーンアップ計画
}

\section{森谷㳯}

\begin{abstract}
米国ワシントン州にある Hanford の DOE 施設は、第二次大戦中から戦後の米ソ冾戦構造の間、核兵器開発の中心的存在 であった。東西対決も終わり、核兵器の廃䋓が進められている中で、かってのPu生産炉や再処理施設の環境回復が大きな問 題としてクロースアップされてきている。

ここでは、Hanford 核兵器開発の歴史を振り返り、Pu 生産とそれに伴う再処理廃亜物の発生と管理状態、177 基に及ぶ廃 畗物タンクの現況とクリーンアップの計画などについて、その概要と問題点について紹介する。

1996 年 9 月以降 DOE は、Project Hanford 管理契約(PHMC)とタンク廃棄物回復システム(TWRS)により、Hanford Tank Waste Cleanup を民間請負化することで、その進捗を計ろうとしている。

Keywords: 高レヘル魔辒物、ハンフォード・クリーシアップ、タンク魔棄物回復システム
\end{abstract}

The US DOE'sHanford Site is the central facilities where the development of nuclear weapons had been made during the World War II and throughout the Cold War years thereafter.

There are 177 tanks to store the wastes produced from the $\mathrm{Pu}$ production facilities after extracting $\mathrm{Pu}$ from the irradiated $\mathrm{U}$ fuels. The constituents of the wastes are very complicated and there still remain highly radioactive nuclides. Not only liquid, but also sludges and solid wastes are remained within the tanks.

This is a brief summary on history and experiences at the Hanford Pu production facilities in general. In order to proceed the Hanford Tank Cleanup Operations, DOE has made the decision to privatize the Project Hanford Management Contract to Fluor Daniel and Tank Waste Remediation System to BNFL Inc. and Lockheed Martin in autumn 1996.

Keywords: HLW, Hanford Cleanup, TWRS

\section{1.はじめに}

第 2 次大戦後米国一旧ソ連間の核開発競争において、 数万個におよぶ核弾頭が製造された。米国においては、 原水爆開発のため16におよぶ大規模な核開発施設が作ら れたが、それらはワシントン、ネバダ、アイダホなどの 州にあった。

ところでこれら核兵器開発施設で生産された製品は、 いかなる産業にもみられない特異なものであった。その 中には 2 万個を上回る核弾頭に用いられたプルトニウム が約 110 トン含まれている。金属ウラン燃料は $\mathrm{Pu}$ 生産炉 の中で然やされ、照射後 Hanford Site や Savannah River Site において再処理されたが、それらは全米における何億力 ロンもの高レベル廃棄物を生み出すことになった。

今日では、これら高レベル廃裹物は、Hanford 177 基、 Savannah River 51 基、Idaho Halls 11 基、West Valley 2 基な どの地下タンクに貯蔵されている。

冷戦解消後、Hanford Site の役割は核兵器開発から、環 境回復、新技術開発、経済面での多角化へと変わってい った。Hanford Cleanup の特徴について言えば、Hanford Tank Cleanup Operations が、全米大の核廃裹物クリーンア ップの中でもっとも規模が大きいということである。エ ネルギー省（DOE）が管理する高レベル廃棄物は容積比 3 分の 2 以上が Hanford サイト内にある。

Hanford では、タンク内廃棄物のクリーンアップが Cleanup Operations の主たる鍵を握っている。Hanfordにあ

\footnotetext{
${ }^{\dagger}$ Hanford Tank Cleanup Operation, by Fukashi Moriya (xr3f-mry@asahinet.or.jp)

${ }^{+}+$海外電力调查会 Japan Electric Power Information Center $\bar{T} 108$ 東京都港 区芝浦 4-15-33
}

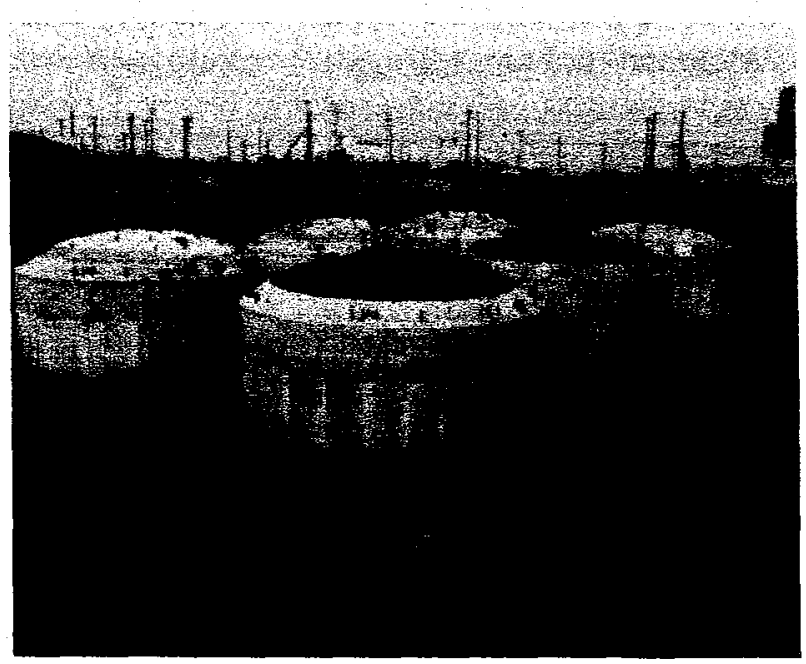

図1 地表面から6 ないし11つィート下に埋設された Hanford の麻车物

るタンク内には、核然料の再処理や放射性物質の回収過 程の中で作られた的 40 種類に及ぶ廃傕物がある。タンク 内廃棄物は、放射性廃㲤物がほとんどであるが、非放射 性廃衰物も含まれている。

なお本報告は、第 2 章ないし第 6 章については主とし て参考文献[1]に基づき、また第7章については参考文献 [2-14]に基づき取りまとめてある。

2. Hanford Site について

\subsection{Hanford Site のあらまし}

Hanford Site はかって Pu を生産していた 560 平方マイ 
ルの土地からなり、現在では DOE が土地の管理も行って いる。その広さはNY マンハッタンの約 25 倍で、ワシン トン州全体の約 $1 \%$ にあたり、南隣りのオレゴン州境まで は25マイルしかない。

Pu 生産の過程において、この Site は DOE 保有の核弹 頭および原子炉グレードPuの約 $60 \%$ （73トン）を生産 している。

\section{2 歴史的背景}

何世紀にもわたって、Hanford の荒涼たる大地は、土着 のいくつかのインディアン種族の住処となっていた。 1855 年に、Yakima Indian Nation と Umatilla Tribe および Nez Perce Tribe が三つの条約に従って、この Site を連邦政 府へ譲渡した。しかし彼らは、狩殍や漁獲、作業用建物 の建設、根菜や果実の収穫、馬や家畜の放牧、持主不明 の土地への権限を保留していた。

\section{3 マンハッタン計画}

土着のインディアンにとって魅力ある広範な空間と豊 富な水に惠まれた Hanford の大地は、第二次大戦の勃発と 共に連邦政府にとっても魅力ある土地として目をつけら れた。

真珠湾攻撃の後、Franklin D. Roosevelt 大統領に対して、 この土地を軍事用の秘密兵器工場の敷地として活用する ことが進言された。そして 1942 年 6 月には軍組織の中に、 マンハッタン計画が発足すると共に、そのリーダーとし

て Leslie Groves 将軍が任命された。

それまでは、Puが産業規模で生産されることはなかっ たわけであるが、Pu生産については大量の電力、希薄な 人口（20マイル以内 1 千人未渵）、10 マイル以内に八イ ウエイや鉄道がない、などの条件を满たす土地が必要だ った。オレゴン州、モンタナ州、ワシントン州東南地区 などに比べて、Hanford が豊富な水資源と人口の多い町が 付近にないことが決め手になって、1943 年 1 月に正式に マンハッタン計画のサイトに決定された。

\section{4 移住亡補荟}

$\mathrm{Pu}$ 生産炬関連施設建設のため、戦時中の特別立法に基 づき、Hanford、Richland、White Buffの町に住んでいた 人たちが、立ち退きを命じられた。延べ 1,200 ないし 1,500 人の人々が 1 エーカーあたり僅か 25 ないし 50 セントの 補償額で、他の地域へ移住を余儀なくされた。地主の多 くはその後土地代金について提訴し、再評価し直して貪 うことが出来た。

いずれにせよ、用地取得後僅か 2 年未渵で、最初の原 子炬、再処理施設、地下貯蔵タンク、燃料成形加工設備 などが操業を開始した。そして、Pu生産施設に加えて、
4,400 戸の住宅、延べ 386 マイルの道路、延べ 158 マイル の鉄道も建設され、操業の最盛期には就労人口は約 5 万 人にもおよんだ。

\section{Pu 生産と再処理廃萧物の発生}

\subsection{Puの生産……産業規模での生産}

$\mathrm{Pu}$ をU から分離すると共に、Hanford にある再処理施 設で生じた化学廃寨物を化学処理するプロセスは、年を 追うと共に変化していった。

まずU燃料はウラン金属の形をしており、その表面は 薄いアルミニウム（後にはジルコニウム）の鞘に収めら れていた。これらの燃料は、1943 年から1963 年にかけて コロンビア川添いの台地に作られた原子炉 9 基のうちの いずれかで然焼されていた。Hanfordにおける原子炉運転 では、延べ 2 千本近くの燃料棒が破損したり、損傷した ことが知られている。そして、放射性物質は原子炬冷却 材中に放出された後、最終的にはコロンビア川まで迻り 着いたことが知られている。

照射済み燃料は、Pu 生産炬から再処理プラント（コロ ンビア川から離れている中央台地上に建設された） 、 特別な遮蔽容器に入れられて鉄道輸送された。1940 年代 から 1950 年代半ばにかけて、再処理プラントは全部で 5 プラント建設された。それらは、各々 $\mathrm{T}$ プラント、B プ ラント、U プラント、REDOX プラント、PUREX プラン トと呼ばれている。

\section{2 再処理プラント}

再処理プラントでは、燃料被覆が先ずアルカリ溶液で 溶解される。次いでウランが酸性溶液で溶解される。 Hanford においては Pu は溶解ウランから回收されたが、 処理プロセス性当初の化学沈降法から、後には溶媒抽出 法へと変わっていった。

この沈降と抽出の過程で、 2 種類の液体廃棄物が生成 された。一つは抽出物で、PuとUを含んでおり、もう一 つは 不溶解物 (raffinate) で廃棄物と考えられるもので ある。 raffinate には全核分裂生成物の $99 \%$ 含まれてい る。

再処理プロセスからは、污染された硝酸溶液、有機溶 剂、各種溶剂、核分裂生成物、各種廃棄物などが発生し てくる。炭素鋼板製の地下貯藏タンクへ配管で移送され る前に、これら高放射性廃充物は苛性ソーダを混入させ て酸性溶液を中和させていた。Hanfordのタンクの中には、 廃液がタンクに送られた後、廃液中から U、Sr， Cs など を回収するために化学処理を追加実施した場合がある。 そのため、Hanfordのタンクに貯蔵された廃液の組成は、 非常に複雑なものである。 


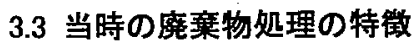

Hanford の当初目的は、国防上の要請に応えて十分な量 のPuを生産することにあった。そのため、長期にわたる 廃棄物処理の問題については、その重要性が認識されて いなかった。つまり、廃棄物の問題は後日解決すればよ いと言うものであった。当時他の産業界での廃䢂物処理 の慣行に做った結果、Hanford の廃棄物マネージメントは、 今日の基準から見れば適切でない方法で処置されていた と言わざるを得ない。

\section{4. 今日の Hanford}

\subsection{Hanford 全般の運営状況}

Hanford Site は、今日では DOEによって管理されてお り、同省は研究開発、DOE の施設操業、労働者の保健な どの業務を民間企業に委託している。1995 年時点では、 Westinghouse Hanford Co. (WHC)、 Bechtel Hanford Inc. (BHI)、Hanford Environmental Health Foundation (HEHF) の 3 社が契約者となっていた。

ところが DOE は、1996 年 10 月から、それまで WHC が担当してきた Hanford クリーンアップ計画の主要業務 を、Project Hanford 管理契約 (PHMC) の名の下に、Fluor Daniel Inc. (FDI) に引き継がせる決定をした。向こう5 年閒にわたる契約金額は 48 億ドルと伝えられている。一 方 WHC は同時期に、Savannah River のクリーンアップ業 務を DOEから受注している。また、著名な研究所である Pacific Northwest Laboratory (PNL) は、環境、エネルギー、 経済、国家安全保障などについて広範に活動しており、 Hanford のタンク・クリーンアップについても長らく関与 してきたことが知られている。

\section{2 規制関係}

DOE やサイト内請負業者の仕事は、連邦政府や州政府 の規制に従わなければならない。規制の主なものには、 包括的環境対策・補償・損害賠償法(CERCLA)、三者協定 （正確には Hanford 連邦施設協定）、資源保存・回復法 (RCRA)の 三つがある。

CERCLA はイスパーファンド」のニックネームをも ち、クリーンアップと有害廃棄物の回復に関する包括的 な淮拠法である。RCRA は、放射性廃棄物の処理、貯蔵、 処分の実行について規制している。三者協定はワシント ン州、EPA と DOE の三者閒の協定であり、DOE がサイ 卜内の液体および固体廃棄物を安全に管理・処分する方 法について規定されている。三者協定では、現在のとこ ろ 2028 年までにクリーンアップの活動を完了すること になっている。

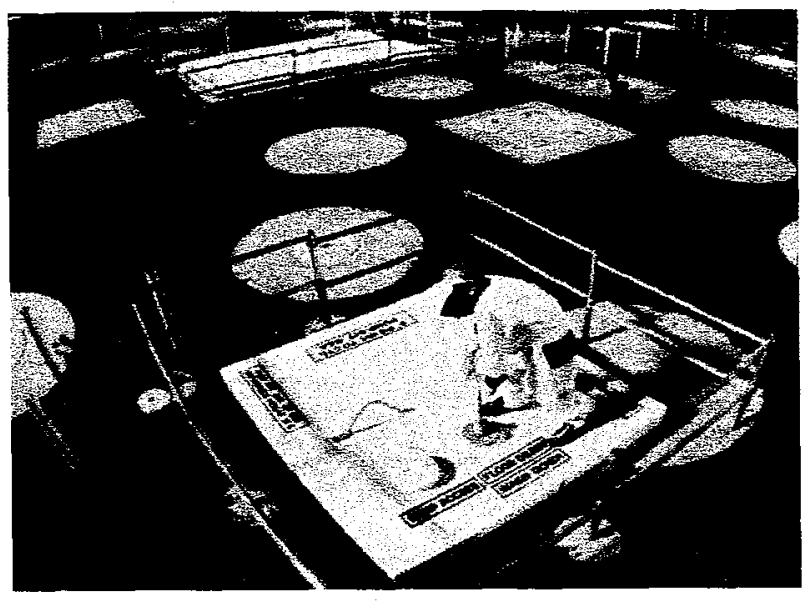

图 2 毎日実施されている廃棄物タンクのモニタリング (出典:PNL-10773)

この他に通常 Wyden Bill と呼称されている Public Law 101-510、Sect 3137 がある。この法律は、DOE に対して Hanford 内のタンクについて監視し、放射性物質の放出を 伴うような温度や圧力の異常な上昇の未然回避を意図し たものである。1995 年 7 月現在でWyden Billに基づき「監 視リスト」タンクに指定されたものは、シングルシェル・ タンクで 48 基、ダブルシェル・タンクで 6 基あった。

Hanford サイトの将来像の決定に関しては、この他 Native American Nations が連邦政府と取り交した協定があ る。 Yakima Indian Nation や Umatilla Indian Reservation Confederated Tribes は共に DOE の Richland Operations Office や DOE Headquarters に助言することができる。更 に Hanford Advisory Board などにおいて、Hanford サイト 内の公式グループとして参加できるようになっている。 また三者協定に基づき、 4 年間に 1 回 Pasco、Kennewick、 Richland $の 3$ 市とワシントンDCにおいて、公聴会が開催 されることになっている。

\section{3 タンクの現況……環境への影響}

操業当初 Hanfordにおいては、コスト削減のため高レベル 廃棄物貯蔵用タンクの材料には、炭素銅が用いられてい た。あるいは、第二次大戦中にはステンレス鋼が不足し て、供給が間に合わないと言うこともあった。

基本的には、Hanfordのタンクは、炭素鋼板を内張りし た円筒形の鉄筋コンクリートで作られている。タンクに は、シングルシェア・タンク 149 基と、ダブルシェル・タ ンク（円環状アンニュラスを備えた） 28 基の 2 種類の夕 ンクがある。アンニュラスがあれば、万一放射性廃液 


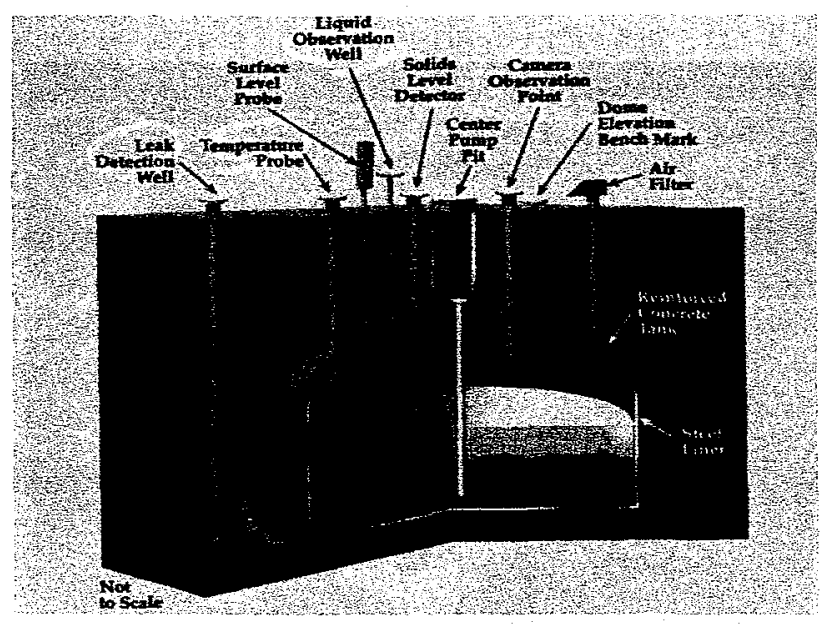

図 3 シングルシェル-タンクの喥念図（サンプリングのア クセスが限られている)（出典:PNL-10773）

が漏れた場合、それを検知して廃液が漏れ出す前に除去 することが出来る。

また、シングルシェル・タンクでは、ドーム部がコン クリートで作られ、鋼板ライナーが使われていなかった。 シングルシェル、ダブルシェルのいずれのタンクについ ても、タンク頂部には土壤や砂利が約 10 フィートの厚さ にかけられていた。

タンクに貯えられた廃液の総量は、約 5,500 万ガロン である。タンク内廃育物の総量が変化してきた理由とし ては、（1）水の蒸発、（2）タンク閒での廃棄物の移送、 （3）施設内からの廃液放出と生産設備の除染、（4）配 管からのフラッシュなどが考えられる。

\section{4 シングルシェル-タンク}

シングルシェル・タンクは、1943 年から 1964 年にか けて作られている。全部で 149 基あるが、それらは次の 4 種類に分類される。（1）55,000 ガロンタンク 16 基、（2） 530,000 ガロンタンクが 60 基、（3）758,000 ガロンタ ンクが 48 基、（4）百万ガロンタンクが 25 基。一番小 さいタンクは、直径 20 フィートで染さ 26 フィートであ るが、一番大きいタンクは直径 75 フィートで樑さが 45 フィートもある。一番大きいタンクの底面の大きさは、 丁度バスケットボール・コートの大きさと同じくらいと 考えてよい。

シングルシェル・タンクは全部で 94 百万ガロンの貯蔵 容量があり、1995 年当時約 35 百万ガロンの廃棄物が収納 されており、その放射能量任約 132 百万キュリー(1996 年 までの減衰を考慮、放射能の $75 \%$ Sr-90 + Y-90、24\% はCs-137)であった。

\section{5 ダブルシェル・タンク}

ダブルシェル・タンクは 1968 年から 1986 年にかけ

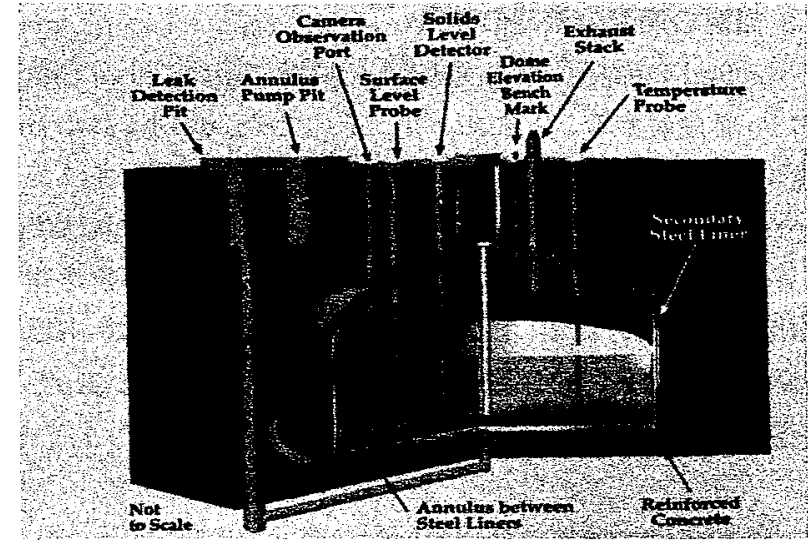

図4 ダブルシェル-タンクの概念図(サンプリングでたくさん のアクセスが可能）(出典:PNL-10773）

て作られた。これには、2 種類あり（1）百万ガロンタン クが 4 基、（2）116 万ガロンタンクが 24 基ある。

ダブルシェル・タンクは全部で 31 百万ガロンの貯蔵容 量があり、1995 年当時約 20 百万ガロンの廃蓑物が収納さ れており、その放射能量は約 82 百万キュリー（1996 年ま での減衰を考慮、放射能の $72 \%$ Cs-137、27\%は Sr-90+ Y-90)であった。

\section{6 タンク内廃液のミステリー}

個々のタンク内の廃液組成は、余りよく知られていな い。大抵のタンクは、照射済みのUから Puを抽出したり、 リサイクル用にUを回収する過程で作られた。遙った種 類の化学プロセスが用いられたが、その中にはHexson や Tributyl Phosphate のような有機化合物や、ビスマスやア ルミニウムなどの各種金属塩がある。酸性廃液がタンク に送られる前に、それらは苛性ソーダで中和された。

その外に各種の材料、例えばイオン交換樹脂、プラス チック・ボトル、金属部品（廃棄物水位剆定用のスチー ルテープ）などもタンク内から発見されている。また、 シングルシェル・タンク内溶液の安定化のためセメント を注入したり、各タンク間でどれ位の廃妄物を移送した のか分からない場合があった。

\section{7 タンク内廃棄物の層状構成}

一般的にタンク内の廃裹物について、その層状構成を 見れば、おおむ福次のようである。

（1）表面に浮いた液体：ポンプで容易に汲み上げるこ とが出来る。

（2）中間液体層：ソールトケーキ（saltcake）とスラッ ジの閒のポーラスな空閒に時折認められる液体で ある。

（3）スラッジ：再処理プロセスにおいて、酸性液体廃 萧物に苛性ソーダを添加した際、タンクの底に沈 
殿した水に溶けない厚い層状の化合物のこと。

（4）蒸気 : 水素、一酸化窒素、アンモニアなどのガス や他の有機・無機ガスは、タンク内廃萧物の放射 線分解や有機化合物の化学的反応などから作られ たものである。

\section{8 有機化合物……複雑な問題}

タンク内の廃棄物には大量の有機化合物が含まれてい る。これらの化合物は、複雑な炭素や水素を含んだ連鎖状 の組成を有している。そして化合物の一部は、PuやUを 分離する過程で廃棄物の中に紛れ込んできたものもある。 あるいは廃棄物の中には、クエン酸や EDTA (ethylenediaminetetra-acetic acid）との複合有機化合物も含まれてい る。そしてこれら有機化合物には、金属や放射性物質が 通常含まれている。複合有機化合物は、1960年代から 1980 年代にかけて、タンク内の廃㲤物から Sr や Cs を取り除 くために用いられた。

今日タンク内の廃棄物については、温度、 $\mathrm{pH}$ 、放射線 レベルなどを測定しているが、その結果わかったことは、 有機化合物がタンク内で発生するガス(水素、一酸化窒素、 アンモニア)の主たる成因になっていることである。これ ら有機化合物は、溶液中に溶解しているため、残余の夕 ンク内廃棄物と化学的に分離することは非常に難しい。 このことが、タンクのクリーンアップに際して放射性物 質を他の金属から分離することを複雑にさせている。

\section{9 地下水の污染}

Hanfordにおいては、お抢よそ150 平方マイルにおよぶ 土地の地下水が污染された。1944 年以降、約 4,440 億ガ ロンに及ぶ液体（放射性物質や毒性物質を含んだ）が、 地下に流れ込んでいった。このうち 3,460 億ガロンは、200 Area から放出されている。200 Area から放出された廃液 中には、約 140 万キュリーの放射能が含まれていた。こ れはHanford Siteの全放射能量の約 $0.3 \%$ に相当している。 そのうち約 20 万キュリーはトリチウムであった。

タンクから放出された廃童物の総量については、誰も が納得できる值は見出されていない。多くの人々が 60 万 ないし 100 万ガロンと推定している。これら廃棄物には、 約 100 万キュリーの放射能があり、その殆どは Cs-137 で ある。しかし、流出した廃液が地下水にまで到達したか どうかは、はっきりしていない。

毎年コロンビア川流域（ワシントン州やカナダ）には、 約 6 千キュリーの放射能が流れ込んでいる。その $98 \%$ 核実験の際大気圈中に放出されたトリチウムに起因して いる。そしてコロンビア川は、Hanford Site を通過する際、 サイト地下の污染による寄与 6 千キュリーを加えて、太 平洋へと流れてゆく。かように、Hanford とその上流地域
からは、毎年 1 万 2 千キュリーの自然および人工の放射 線源が、コロンビア川を流れ下っている。

\section{Hanford タンクのクリーンアップ}

\section{1 クリーンアップのコストはいくらになるか?}

「クリーンアップ」の定義の仕方によって、クリーン アップのコスト、スケジュール、人体への影響、必要な 技術のあり方が変わってくる。既存の技術の中にも、そ のままクリーンテップに利用できるもの（例えば Savannah River Site におけるガラス固化）もある。しかし、 Hanford にあるタンク内溶液の物性が複雑多岐にわたう ている以上、多くの技術を駆使してゆく必要があると考 えられている。

現時点での推定では、Hanford Cleanup は数百億ドルか ら、数千億ドルの範囲にわたっている。かように、推定に 大きな幅があるのは、クリーンアップのやり方について、 (1)クリーンアップが必要とされるレベル、(2)クリーンア ップ後のサイトの利用法、(3)廃衰物の最終形態のあり方 などについて分からないことがたくさんあるからである。

\subsection{Hanford のタンクにおけるガスの蓄積}

1995 年 6 月までに、シングルシェル・タンク 19 基、ダ ブルシェル・タンク 6 基で定期的に水素、一酸化二窒素 $\left(\mathrm{N}_{2} \mathrm{O}\right)$ 、窒素、アンモニアなどのガスが放出されたこと が監視されている。それらは、タンクの監視リスト基準 を上回ったものであった。水素の放出量が大きければ、 ガス性懪発してしまう恐れがある。

例えば、ダブルシェルの SY-101 タンクでは、大量の水 素ガスを放出したことがあり、ガスの蓄積を減じるため に、いろいろな手段を講じてきた。ガスの蓄積によりタ ンク内廃棄物の表層レベルが約 1 フィートも変わったこ とがある。1993 年に 7 階建ての高さのミキサーポンプが 据え付けられる前には、 3 ないし 4 ヶ月に 1 回ガスのバー プが起こった。SY-101 タンクでは、かって水素ガス蓄積 が火災レベルを超えたことがある。

しかし1996 年 10月、DOE は SY-101 タンクについて、 もはや 着火性ガス発生の問題は消滅したと報告してい る（大型ミキサーポンプはその後も順調に稼動中してい る)。

\section{6. タンク内鹿棄物}

\section{1 タンク内廃充物の組成}

Hanfordにおいては、核然料再処理について複雑で長 い歴史があり、他の DOE あるいは国際的な施設よりも、 タンク内廃棄物の組成が非常に複雑になっている。それ 


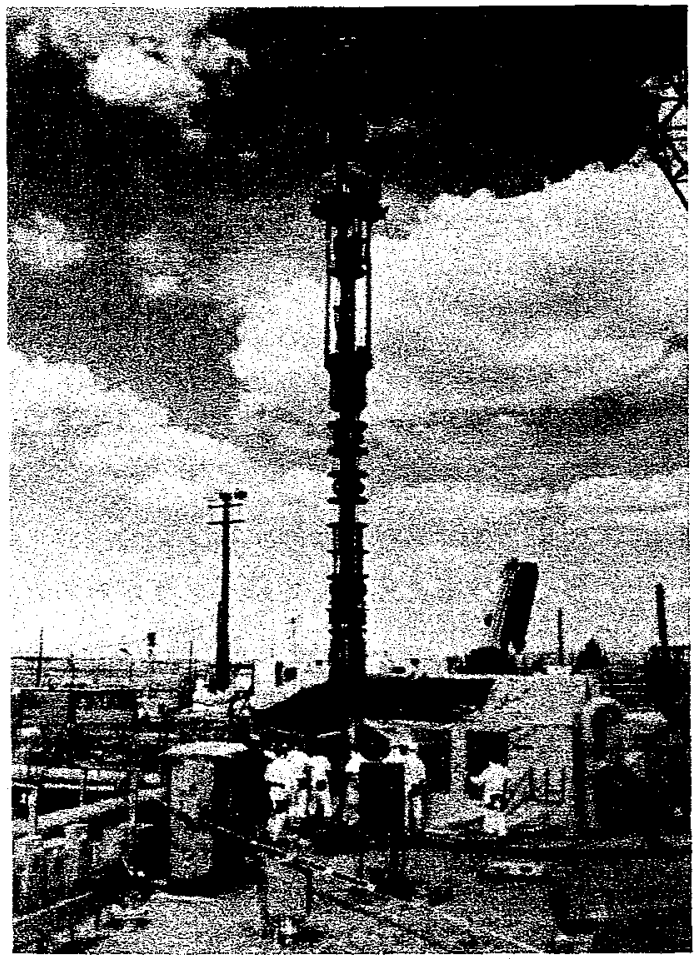

図5 SYー101 タンクのミキサーポンプの設置状況 (水素を始めとするガスの放出抑制に役立っ

た) (出典:PNL-10773)

らの要因を列挙しておけば、次のようである。

・照射済み燃料の再処理に、いろいろなプロセスが用い られた。

・再処理廃裹物プラントからの酸性廃液は苛性ソーダで 中和している。一般的にセシウムはおおむる溶液中に 溶解しているが、プルトニウムの錯塩はタンクの底に 溜まっている。

・いくつかのタンクでは廃液が蒸発して、固いソールト ケーキや厚いスラリーが作られた。

・いくつかのタンクでは、セシウムやストロンチウムを 沈殿させるために、シアン化鉄が添加された（放射性 レベルの低い液体を土壌中に放出させるため）。なお 1996 年 10 月、DOE は試料分析の結果、シアン化鉄に ついて安全性の問題は解消したと発表している。

・操業初期の段階でいくつかのタンクでは、液体廃䢂物 を安定化させるために、セメントや珪素土を添加した ことがある。

かよらに、一つのタンク内で廃衰物の組成を知ること が難しいばかりでなく、処理コストも高くなってくる。 177 基それぞれのタンクについて、いくつかのサンプル （スラッジ、スラリー、上澄み液など）採取がタンク内 廃衰物の各層ごとに必要と考えられている。

\section{2 廃辌物除去について}

廃棄物を処理するために移送する際には、いろいろな ことを考えておかなければならない。タンクから放射性 廃棄物を抜き取る際には、遠隔操作が必要となってくる。 タンク頂部の小さな開口部（直径 42 インチ未満）を通じ て、廃㶳物を取り扱うのには、いろいろな制約がある。

次に廃革物が除去作業に際して、物理的組成がどう変

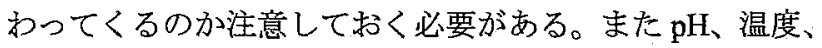
化学濃度、混合物組成などが、除去作業の際どう変わつ てくるのか検討しておかなければならない。

\section{3 具体的な除去方法の検討}

現段階で検討されているタンクからの廃棄物除去手法 としては、次のようになっている。

(1)ミキサーポンプ

これは、廃棄物の組成が基本的に液体状で、擤找させな がら廃棄物を地中に漏洩させることなく移送できる場合 に適用できる。

（2）水圧カット法 (Hydraulic Slicing)

古いシングルシェル・タンクについて作業する場合には、 今後再び漏洩などを生じないような配慮が必要になって くる。この場合有効なのが水圧カット法により、タンク 内の廃媟物（ソールトケーキやスラリー）に吹きつけて、 廃裹物をスライス状に切断してゆく方法である。

(3) ロボットアーム

シングルシェル・タンクによく見られるソールトケーキ の固まり、あるいは固体廃充物（プラスチック・ボトル やイオン交換㴻脂）などは、ロボットアームを用いて切 断される。Tank Cleanup の場合には、高放射線環境、あ るいは狭い空閒を通したり曲げたりする技術が必要にな ってくる。スペースシャトルのロボットアームで知られ るカナダの Spar Aerospace Ltd. が開発した遠隔操作ロボ ット（英文名 light-duty utility arm）が、1996 年 6 月以降、 Hanford を含むDOE 施設 4 ヶ所（外にINEL、ORNLなど） において試験使用が行われている。

\section{4 庆䢂物の前処理}

タンク内廃萧物の前処理の特徵は、固体成分を液体か ら取り除き、溶解性物質も固体側に紛れ込ませないよう にすることである。液体成分には、硝酸塩などの高濃度 の塩にCsが含まれている。Csさえ取り除いてしまえば、 残った廃液の放射能は、低レベル廃液として処理できる 程低いものになる。これは、高レベル廃裹物の量を減らす ことを意味する。

前処理の関連で研究が進められていることに、強酸む しくは強アルカリ性の化学溶液による、廃率物の洗浄と 廃㲤物の最終形態で邪魔になる化学物質の除去がある。 


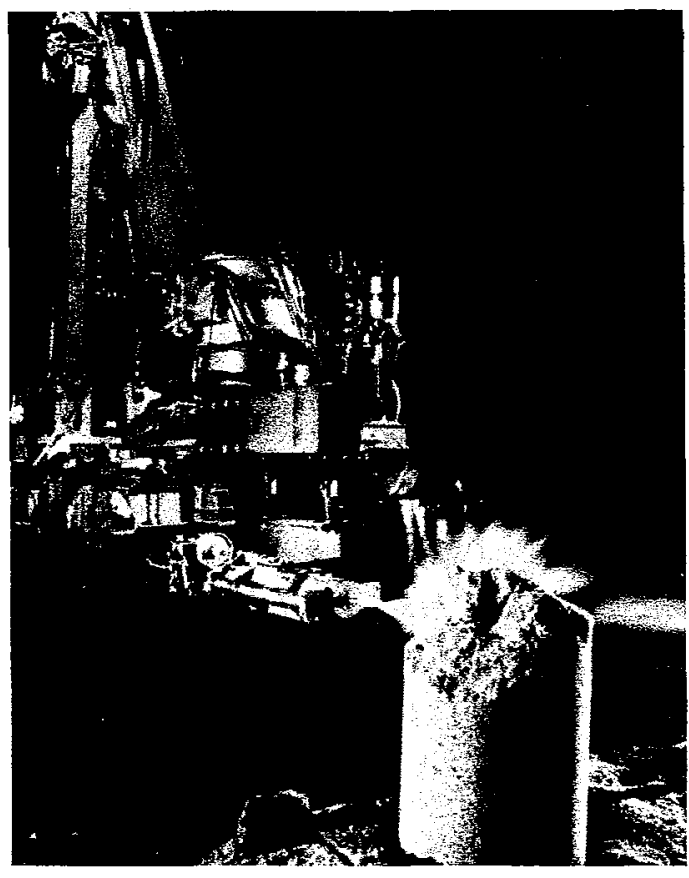

図6 水圧カット工法の実証試験状況（模擬 saltcake を水 圧で小さな塊に切断できることを確認)（出典:PNL10773)

その理由は、もし廃葉物をガラス固化する場合、アルミ 二ウム、橉、クロムの含有量を減らしておけば、耐久性 ある高レベルガラス固化体を作り出すことができ、かつ これらの金属を取り除いておけば、高レベルガラス固化 体の総容積を減らすことができるからである。

\section{Tank Waste Cleanup の実施準備進む}

民間請負化

c

\section{1 予算関係}

Hanford に対する連邦予算投入の状況を整理しておく と、米政府は 1989 年に調印した三者協定に基づき、1995 会計年度末までに Hanford クリーンアップのために約 75 億ドルを出費している。1996 年度には 16.5 億ドルが出費 され、97 年度には 14.7 億ドルの出費が見込まれている。

ところで 1998 年度の予算要求は 17.3 億ドルとなってい るが、その用途別内訳は次のようになっている。

・タンク廃棄物回復システム(TWRS)の民間請負化 427 百万ドル

・ TWRS 316 百万ドル

・その他廃査物管理 141 百万ドル

・環境回復 132 百万ドル

・核物質および施設の安定化 406 百万ドル

・その他環境管理 114 百万ドル

・将来の建設用資金 202 百万ドル

\section{2 包括的な視点……米議会への要請}

米国議会が検討すべき主要課題として、「エネルギー天 然資源委員会」が挙げている問題点をまとめておけば、次 のようである。

・クリーンアップの法的・規制上の枠組みの改変

・実際に適用すべきクリーンアップ・レベル問題の解決

・DOE が Hanford に適用すべき統合的リスク評価を行う ベきこと

・DOE が Hanford クリーンアップ長期計画を作成し、定 期的に見直してゆくべきこと。その際、廃衰物管理、 施設の完全除染、環境回復について検討すること

\subsection{Project Hanford 管理契約 (PHMC) について}

DOE 長官に O'Leary 女史が就任してから、DOE では Hanford のクリーンアップ事業を民間請負化し、民閒活力 を活かして予算削減に努力する動きが出てきた。まず 1995 年 11 月にタンク内廃棄物のクリーンアップ作業民 間請負化の方針が打ち出された。そして 1996 年 2 月には、 Project Hanford 管理契約 (PHMC) をコスト清算方式から 固定価格方式(処理廃棄物の単価を固定する)に切り替え た。O'Leary 長官は、「これでクリーンアップコストが $30 \%$ 安く出来、米国の納税者たちにとって大きな勝利に なる」と説明している。

\section{4 タンク廃棄物回復システム(TWRS)の実施状況 —-. DOE 予算報告から}

DOE Hanford の予算報告資料によれば、1997 会計年度 の実施計画として次のように報告されている。

・シングルシェルタンク 149 基中 119 基を安定化（達成 率 $80 \%$ )

・シングルシェルタンクファーム 12 個所中 3 個所を中閒 安定状態化 $(25 \%)$

・タンク 112 基について Characterization Report を作成 $(63 \%)$

・106-C 高熱タンクから廃棄物の除去を開始 また 1998 会計年度においては、次が計画されているこ とが分かる。

・新規サイト内横断移送配管の使用開始

・シングルシェルタンクについて更に 5 基の安定化を達 成（達成率 $83 \%$ )

・シングルシェルタンクファーム 2 個所を更に中間安定 状態化 $(42 \%)$

・タンク 20 基について Characterization Report を作成 $(74 \%)$

・100 万平方フィートにわたるタンクファーム表面污染 の清浄化達成 
・民間委託化 TWRS について、請負業者による廃亩物 Remediation 施設の建設を開始

\subsection{TWRS を巡る動き}

タンク廃棄物回復システム (TWRS) については、段階 別に民営化が進められることが 1996 年 9 月に決まり、実 証段階の Phase I については BNFL Inc. と Lockeed Martin Advanced Environmental Systems の 2 社が受注した。Phase I の Part Aについては、20 ケ月の間に民営化したタンク 処理施設の技術、規制、経済性を確立することが要請さ れており、そのため前記 2 社に詨してそれぞれ 2,700万ド ルの固定価格が保証されている。

また PartB 段階でも 2 社閒の競合により、タンク廃菓 物の6 ないし $13 \%$ \%つて、固定価格ベースで実証を進 めるとしている。DOEでは、PartB には 10 ないし 14 年 を要し、その間 50 億ドル以上の出費が見込まれるとして いる。

クリーンアップは、フルスケール操業段階の Phase II において完了させるとしている。ちなみに三者協定では、 2028 年までにすべての廃棄物を固化して、最終処分の準 備を整えることになっている。

ところで 1996年 1月 26日付けの米国会計検查院 (GAO) 長宫から DOE の O'Leary 長官宛て書簡 (GAO/RCED-9656）によれば、TWRS 所要資金は述べ 360 億ドル以上に達 するものと予想されている

\section{8. おわりに}

TWRS が漸く実施に向けてスタートし、戦後半世紀以 上にわたり滞っていた Hanford Tank Waste の Cleanup が進 渉する運びになったのは、この問題に関心を寄せていた 者として大変喜ばしいところである。

しかし、DOE 施設内に民間施設の建設を認めることに なれば、新たに DOE 施設に対する NRC による規制重複 の問題が生じてこよう（TWRS に関しては DOE と NRC の間で覚書(MOU)が 1997 年 1 月に締結されている模様)。 そしてTWRS 民間請負施設（Vitrification 施設など）につ いては、最終的には解体撤去が義務づけられているよう である。また、BNFL Inc.チームについては、GTS Duratek 社が参加しており、ガラス固化技術は Sellafield の Vitirification Process ではなく、米国における同社の革 新的な技術が採用されるとのことである。また PHMCに おいては Fluor Daniel チームの傘下に Numatec Hanford Inc. が加わっているが、同社の親会社は Cogema/SGN である のも注目を惹く。

1997 年 1 月には、DOE 長官には O’Leary 女史に代わっ
て Penya 氏が任命されているが、前長官時代に引かれた 民営化推進を中心とする DOE の基本路線は、そのまま踏 襲されていくものと考えられる。

また、本稿の取りまとめに際しては、情報革命の旗手 であるInternetによる情報入手が大きな役割を果たしてく れた。DOE Press Release を始めとする米国政府機関の情 報の透明性と公開の進捗ぶりには目を見張らせるものが あり、我が国としても大いに学んでゅかる゙ばならないと ころであろう。

最後に: 最新の情報入手に㙝力してくれた米国の二人 友人、Roger Gale（WIEG）社長と John Graham（BNFL Inc.) 副社長（前 ANS 会長）に感謝しておきたい。お二 人の協力により、Hanford Tank Cleanup に関する最近の情 報を入手する鍵を得ることが出来た。長年の友情に感謝 して筆を置くことにしたい。

\section{参考文献}

[1] Gephart, R. E., Lundgren, R. E.: Hanford Tank Clean up: A Guide to Understanding the Technical Issues, PNL10773, Pacific Northwest Laboratory (1996).

[2] Blush, S. M., Heitman, T. H.: Train Wreck Along the River of Money: An Evaluation of the Hanford Cleanup, Report for US State Committee on Energy and Natural Resources (1995).

[3] Kramer, D.: DOE picks Fluor team to manage Hanford Site etc., Inside Energy, Aug. 12, 1996, 3-4 (1996).

[4] Kramer, D.: DOE Sites to begin using robotic arm to treat waste in tanks, Inside Energy, June 3, 1996, 8-9 (1996).

[5] GAO/RCED-96-56, Hanford's Tank Waste Characterization: B-270726, Jan. 26, 1996, US General Accounting Office (1996).

[6] Holloway, K., Brady, J.: Energy Department proposes to privatize Hanford's Radioactive Tank Waste Cleanup, DOE Press Release, Feb. 20, 1996.

[7] Curtis, N.: A New Era for Hanford: Fluor-Daniel team assumes cleanup responsibilities, DOE Press Release, Oct. $1,1996$.

[8] Schein, G.: Clinton Administration selects teams for first phase of Hanford Tank Waste Cleanup, DOE Press Release Sept. 25, 1996.

[9] Schlesinger J.: BNFL Inc. wins Largest DOE Privatization Contract, BNFL Press Release, Sept. 25, 1996.

[10] Hanford Tanks Initiative : Hanford Homepage, Feb. 11, 1997, http://www.hanford.gov/ (1997).

[11] Berriochoa, M.: Hanford announces major progress with tank safety issues, DOE Press Release Oct. 30, 1996.

[12] DOE's Fiscal Year 1998 Budget Presentation for the Hanford Site: Hanford Homepage, http://www.Hanford. gov/doe/budget98/ (1997). 
[13] Gale, R.: Private Connection, Feb. 19, 1997.

[14] Graham, J.: Private Connection, Feb. 25, 1997. 